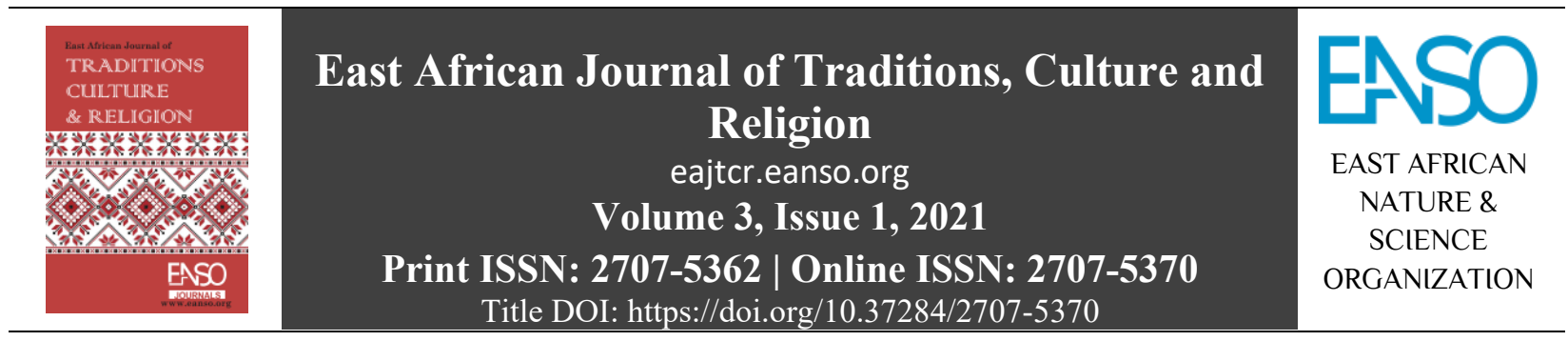

Original Article

\title{
Ethical Dimensions of Entrepreneurial Practice in Three Traditions
}

\author{
Dr. Joseph Situma, PhD ${ }^{1^{*}} \&$ Prof. Stephen Ifedha Akaranga PhD \\ ${ }^{1}$ Department of Philosophy and Religious, University of Nairobi, Nairobi, Kenya. \\ *Author for Correspondence Email: situmansituma@gmail.com
}

Article DOI: https://doi.org/10.37284/eajtcr.3.1.317

Date Published:

09 April 2021

\section{ABSTRACT}

Entrepreneurs are a category of agents who are found in all human societies and

Keywords: their significance has been variously assessed. Although they are a universal phenomenon, their repertoire of activities, thoughts, motivations and emotions

Entrepreneurial, appear to be tradition-specific. This paper considers entrepreneurial practice in

Practice, the liberal, libertarian, and communitarian traditions. The first objective is to

determine if the primary ethical dimensions of entrepreneurial practice are Tradition, structured by tradition. The second objective is to evaluate the status of Social Good, entrepreneurial practice in the three traditions vis-à-vis common good. The Virtues, paper uses the conceptual framework of tradition and its allied concepts of Moral Violation. practice and narrative. It concludes that although the primary ethical dimensions of entrepreneurial practice arise from a tradition, novel entrepreneurial practices depart from tradition-set norms. It also concludes that entrepreneurial practices can and do violate the common good-more so in the liberal and libertarian tradition.

\section{APA CITATION}

Situma, J., \& Akaranga, S. I. (2021). Ethical Dimensions of Entrepreneurial Practice in Three Traditions. East African Journal of Traditions, Culture and Religion, 3(1), 23-34. https://doi.org/10.37284/eajtcr.3.1. 317

\section{CHICAGO CITATION}

Situma, Joseph, and Stephen Ifedha Akaranga. 2021. "Ethical Dimensions of Entrepreneurial Practice in Three Traditions". East African Journal of Traditions, Culture and Religion 3 (1), 23-34. https://doi.org/10.37284/eajtcr.3.1. 317.

\section{HARVARD CITATION}

Situma, J. and Akaranga, S. I. (2021) “Ethical Dimensions of Entrepreneurial Practice in Three Traditions", East African Journal of Traditions, Culture and Religion, 3(1), pp. 23-34. doi: 10.37284/eajtcr.3.1. 317.

\section{IEEE CITATION}

J. Situma, and S. I. Akaranga, "Ethical Dimensions of Entrepreneurial Practice in Three Traditions", EAJTCR, vol. 3, no. 1, pp. 23-34, Apr. 2021. 


\section{MLA CITATION}

Situma, Joseph, and Stephen Ifedha Akaranga. "Ethical Dimensions of Entrepreneurial Practice in Three Traditions". East African Journal of Traditions, Culture and Religion, Vol. 3, no. 1, Apr. 2021, pp. 23-34, doi:10.37284/eajtcr.3.1. 317.

\section{INTRODUCTION}

World over, entrepreneurship is recognized as a practice that enables human beings, societies and countries to realize social and economic growth and development. There have been entrepreneurs from time immemorial and in the $20^{\text {th }}$ and $21^{\text {st }}$ centuries, many governments have launched entrepreneurship education programs (Vesper \& Gartner, 1997; Solomon et al., 2002; Klein \& Bullock, 2006). Perhaps, this trend is prompted by the argument that ability to be entrepreneurial is acquired through education and experience. Thus, Drucker (1985) asserts that 'It's not magic, it's not mysterious, and it has nothing to do with genes. It's a discipline that could be learned". Politis (2005) presents a framework for ensuring optimal learning of entrepreneurship. Entrepreneurs like other human beings are, however, driven by internal and external motivation, aspects of which are not just generally beyond the scope of most curricula but are possibly not learned (Aristotle, 1999; MacIntyre, 1984; Deci \& Ryan, 1985; Cordon, 2003). Moreover, there are various kinds of entrepreneurial practices and traditions in which they are deployed. The ethical dimension of entrepreneurial practice merits philosophical attention as exemplified in this paper.

The first objective of this paper is to determine whether the primary features of entrepreneurial practice are structured by traditions. The second objective is to evaluate entrepreneurial practice in the three traditions vis-à-vis common good. This explorative discourse is further guided by two hypotheses: First, the primary features of entrepreneurial practice are not determined by the social tradition in which they are deployed. Second, the primary features of entrepreneurial practice are not in harmony with the common good.

An aspect is a primary feature of entrepreneurial practice if and only if it is necessary for an action or set of actions to be designated as entrepreneurial. The concept imposes a requirement that an action must meet. It is strange to hypothesize that the primary features of entrepreneurial practice are in conflict with the common good because a practice is a pattern of action that a tradition permits. This paper adopts Beerbohm and Davis's (2017) criteria of common good, namely that; "it should be distributively neutral, non-partisan, and extensionally adequate".

\section{Entrepreneurial Practices and Traditions}

A tradition can be understood as an established and visible mode of operation that is employed by human beings in undertaking their activities will feature in morals, laws, and all their transactions (MacIntyre, 1984). A group of people who co-exist over an extended period develop unique ways of fulfilling their needs; that is a tradition. In view of this, what are the primary features of entrepreneurial practices in various traditions? And how do the primary features of entrepreneurial practices stand vis-à-vis common good in various traditions?

Three traditions are focused on in this paper; namely the liberal, libertarian, and communitarian traditions. Of the three, the liberal tradition is the foremost established and forerunner tradition. Among its most visible proponents are Smith (1976), Locke (1997), Kant (1996), and John Rawls (1971). This tradition not only emphasizes individual liberty but also underscores principles of equality and utility. The latter aspects, viz. equality and utility form the basis for neoliberal policies that strive to secure certain patterns of distribution of goods and opportunities and institutional mechanisms that intervene in the market to ensure social utility.

The libertarian tradition's key proponents include Friedman (1962), Rand (1957, 1964), Gilder (1982) and Nozick (1974). These libertarian thinkers hold the view that human beings are at liberty to choose, actualize and utilize their values. This tradition's point of departure from the liberal tradition is that the self ought to be the primary focus of a human being's action. In other words, social benefits accrue from agent action largely by coinciding with self-interests. In this model, the agent has no 'social' obligations, but this does not necessarily entail actions that the agent violates social good. Rand $(1957,1964)$ stands out in her explicit arguments for 
the virtues of rationality and self-interest. She posits that it is not feasible for a rational agent to engage in practices that violate rational self-interests and rational social interests (i.e., interests of family, friends, neighbours, and community).

The communitarian tradition is traced to Aristotle (1984), MacIntyre (1984), Sandel (1982), Etzioni (1988) and Selznick (1992). Communitarianism distinguishes and emphasizes the constitutive value of social milieu which requires "instilling social values that stress judging what is morally right as opposed to always considering individual rights". It also argues for "giving the locus of policy-making power ...to the community and ensuring that all members of that community be given a voice in shaping policies affecting their lives; and returning to the democratic idea of civic participation" (Theobald \& Dinkleman, 1995).

While the concept of common good features in deliberations of societies in the three traditions, the process of determining specific objects and affairs that qualify to be on the list of common good is complicated and fraught with misconceptions and manipulation. Is it the case that entrepreneurial practices which arise in social traditions are in conflict with the common good? Are entrepreneurial practices in conflict with the common good? If so, how can this be accounted for, in view of the reality of tradition and the widespread commitment to entrepreneurship?

The concept of 'entrepreneurial practice' implies a reiterated process of conceiving, establishing, and developing an entity with the conscious or unconscious aim of actualizing value(s). A more elaborate definition of entrepreneurship is that it is "an individual's ability to turn ideas into action. It includes creativity, innovation and taking a calculated risk, as well as the ability to plan and manage projects or to achieve objectives" (Gedvilienė \& Bortkevičienè, 2013).

\section{RESEARCH METHODOLOGY}

The concept of tradition entails practice and narratives. MacIntyre (1984) defines a practice as a socially established mode of undertaking a specific activity and argues that a practice has both external and internal goods. Gartner et al (2016, p. 2). define a practice as "a routinized type of human performance consisting of ...forms of bodily activities, forms of mental activities, 'tolls' and their use, background knowledge in the form of understanding and know-how, states of emotions and motivational knowledge". Practice refers to actions that arise from habits and tacit knowledge of agents that are outcomes of a specific social, cultural, and economic environment (Aristotle, 1999; MacIntyre, 1984; Bourdieu, 1972; 1990; Giddens, 1984; Ortner, 2001). The fact that a practice is manifested in human beings' actions, which might fall short of the prescriptions, means that the concept is heuristically appropriate for studying individual endeavours which are situated, have a beginning, middle, and an end.

Apart from the narrative being entailed in the concepts of tradition and practice, Johansson (2004) points out that; "in recent years it has...been suggested that entrepreneurship research would benefit from the use of a narrative approach...by enriching the understanding of what motivates individual entrepreneurs and the way they run their businesses". Narratives are reconstructions of entrepreneurs' experiences as remembered and told by various sources. The selection of narrative details is determined by the research hypotheses (Etherington, 2011). In considering entrepreneurial practices, this paper analyses select narratives from the liberal, libertarian, and communitarian traditions. Each entrepreneurial narrative is analysed basing on the following themes:

a) Industry and commitment

b) Workers, shareholders, customers, and stakeholders

c) Social good

\section{ANALYSIS OF ENTREPRENEURIAL PRACTICES IN LIBERAL, LIBERTARIAN, AND COMMUNITARIAN TRADITIONS}

The entrepreneurial practices of Ted Turner (Hisrich \& Peters, 2002, p. 3-6), Lillian Vernon Katz (Hisrich \& Peters, 2002, p. 63-65), and Malachi Mixon III (Hisrich \& Peters, 2002, p. 87$89)$ were analysed in the liberal tradition. These practices are generally guided by reason, passion, and intuition. The epistemic and emotive aspects 
arise from greed, utility, contingency and individual wellbeing whose entrepreneurial practices are constrained by liberal legal requirements. The liberal tradition permits multiple visions, sets of norms and values, and divergent principles, and therefore entrepreneurial practices are hardly guided by any of these aspects.

Aside from compelling social and legal requirements and dynamics, entrepreneurs deploy their abilities (virtues) to maximize profit and ensure the growth of their enterprise with a rare or muted focus on the common good. Instances of entrepreneurial practices violating the common good arise from the liberal tradition's emphasis on negotiated and debated determination of the common good. The process of negotiation and debate is open to power dynamics, varying individual abilities and media access. Concordance of liberal entrepreneurial practices with common good is rarely the outcome of moral considerations, but coincidences of common good with interests of the enterprise. This is evident in McDonald's emphasis on "high standard of cleanliness and consistency of service" (Peters \& Waterman, 1982, p. 9), Hewlett-Packard's practice of being close to customers (Peters \& Waterman, 1982, p. xix) and Cable News Network's global reach and appeal in news coverage (Hisrich \& Peters, 2002, p. 5).

Heterogeneity of visions and concepts of social good in this tradition is a fundamental factor that accounts for apparent violations of the common good. Reynolds (2006) attributes this to cognitive heterogeneity and argues that as a result of this feature, entrepreneurs will have diverse moral sensibilities. Expediency in the liberal tradition is a product of its sophist heritage (Almond, 1990; Torcello, 2011) which is most visible in the conduct of entrepreneurial practices at the inception of enterprise. At this stage, entrepreneurs "damn the bureaucracy and manoeuvre their projects through the system and out to the customer" (Peters \& Waterman, 1982, p. xviii). The fact that the sense of community is diminished and transient accounts for marginal or total lack of consideration of common good (Shaw, 1997; Spinosa et al., 1997; Lasch, 1978). Marginal or lack of consideration of social good by most liberal entrepreneurs does not, however, necessarily entail that their practices violate social good. Non-violation of the common good in this kind of case is incidental. It is even logically possible to have a situation where fairness or procedural justice is an important element of the entrepreneurs' relationship with key investors as Sapienza and Korsgaard (1996) assert and violations of common good. Specific procedures of justice's secure common good is conditional on many factors. But, due to marginalization of moral prerogatives and the dominance of legal prerogatives, liberal tradition entrepreneurial practices are significantly structured by legal constraints and dependent on surveillance(reference). They could be inherently limited, but violations of social good in the early stages of enterprises in the liberal tradition arise from this limitation, coupled with the rise of emotivism and positivism. Common good is assumed to be secured when there is satisfaction which is often manipulated. Statistical indications on the other hand based on, common good are varied and highly questionable.

The liberal tradition ultimately conceives and permits even the most wicked entrepreneurs to set up, build, and run their enterprises. John Maynard Keynes (1973) asserts that; "Capitalism is the astounding belief that the most wicked of men will do the most wicked things for the great good of everyone." The view of liberal entrepreneurial practices has been invalidated by the 1948 Universal Declaration of Human Rights and the 1966 Covenant on Social, Economic, and Cultural Rights which emphasize that parties ought to ensure the wellbeing of citizens, viz. common good. In other words, the common good could only be secured through specific legislation that compel entrepreneurs to desist from certain actions and to undertake certain activities in their enterprises.

If entrepreneurial practice is defined as a "reiterated process of conceiving, establishing, and developing an entity with the conscious or unconscious aim of actualizing value(s)", then, how does the violation of common good arise? Perhaps this could be due to the lack of emotional commitment of the entrepreneur to the enterprise. However, fundamental violation of the common good could arise when entrepreneurial engagement transcends either the reiterated process of conceiving, establishing, and developing an enterprise or the archetypal enterprise. Howard-Hassman and 
Donnelly (1999) point out that although the liberal aspect of free-market serves social good, there are instances in which the market rewards morally undeserving and instances in which it undermines the overall good of society.

Fenton and Langley (2011) capture the nefarious covert strategy that entrepreneurs adopt at their peak: " ... at their most powerful they seek to co-opt officials and politicians for their agenda" and in the process "risks are...carried by communities and ecological systems and ...costs are born by communities (tax-payers) and future generations". This is an instance of contrived construction of common good where there is a preponderance of harm over good. This is affected through lobbying, legislation, policies, and development strategies. Entrepreneurial practices in some of the large and established enterprises are likely to undermine the common good. The impersonal juggernaut of the $18^{\text {th }}$ and $19^{\text {th }}$ centuries never left the stage; it only became subtler and invasive. This is not to deny that the liberal tradition's entrepreneurial practices generate efficiency, which generally ensures easier access to commodities and opportunities for citizens, and increased revenue for exchequers. Efficiency, easier access to commodities and opportunities could only be one part of the equation of human wellbeing. The other part of the equation includes the spiritual, psycho-social aspects of human beings, which are arguably neglected or diminished under the liberal mantra of commoditization (Fromm, 1991).

Out of the diverse but common position that the liberal tradition is flawed, the libertarian and communitarian traditions emerge. HowardHassman and Donnelley (1999) assert that libertarian and communitarian traditions have their pedigree in liberalism. The libertarian tradition emphasizes liberty and minimal state as exemplified by Peter Thiel (O'Dea, 2016), a United States entrepreneur who espouses 'contrarian thinking' arguing that the liberal striving against monopoly is misconceived. This outlook reflects the strong influence of Rand (1959) and Irving (2011), who both eschew political correctness and vehemently argue for deregulation. While the libertarian entrepreneur is also driven by greed for wealth, like liberal entrepreneurs, the influence of Girard's (1987) mimetic theory of desire sets him apart through his striving to create unique values rather than participating in creating values that everyone else is producing. He asks; "What valuable company is nobody building? (O'Dea, 2016)"

The net effect of Thiel's (O'Dea, 2016) outlook is that his entrepreneurial practices "strive to innovate outdated or often non-existing practices" as expressed by SpaceX and Seasteading (O'Dea, 2016). Thiel's anti-correctness stance echoes Ayn Rand's character's in The Fountainhead (1943) and Atlas Shrugged (1957). In these works, Thiel is explicitly against state or any agent's contrived construction of common good, granted that assertion of a common good presumes that what is good should be the "organizing principle of civic and political life" (Etzioni, 1988). In reference to fictional entrepreneurs that Ayn Rand presents in Atlas Shrugged, and Hayek, every attempt is made by Thiel to determine common valuable objects and practices which offend the principle of liberty and are a recipe for totalitarianism.

Peter Thiel's (O'Dea, 2016) investments such as PayPal, Facebook, SpaceX, Privateer Holdings, and Palantir Technologies, to a large extent, reflect his libertarian commitment to enhancing human beings' liberty and establishing realms that are well beyond the reach of government controls.

The use of fictional entrepreneurs such Jon Galt, Daigny and Rearden follows in the footsteps of Krieger (1996) who analyses the entrepreneurial vocations of Biblical Moses, St Augustine, and Shakespeare's Antigone, just to name a few. The libertarian worldview is presented by Rand (1963), Nozick (1974), Reiman (1996), Hayek (1944) and Huebert (2010). This tradition grounds right and justice on individual liberty and prohibits actions, laws, and institutions that violate individual good, and it is averse to the common good.

Libertarian entrepreneurial practices are determined by tradition. But this is largely a matter of logic and the concept of tradition. A libertarian entrepreneur such as Thiel is logically averse to certain invocations of common good. Etizioni (1988) states that the concept of common good is "a normative concept with a long and contested history". Ayn Rand contests the invocation of 'common good' of irrational people because, it is practically difficult but not impossible to construct a list of goods that 
equally serve all members of a given community and its institutions (Beerbohm \& Davis, 2017).

Libertarian philosophers emphasize the virtue of rationality. But rationality can only be exercised properly with other cardinal virtues. The significance of justice, temperance, fortitude, and prudence cannot be gainsaid. This could be ascertained if sound judgment could perceive the necessity of these virtues. At some point, the libertarian entrepreneur ought to stand back and reflect on the worthiness of enterprise. An example is the Founders Fund, where Thiel has invested in researches that address issues of human health and the problem of ageing. His investment in marijuana, despite criticisms, reflects the uncritical commitment to advancing individual liberty without care about purpose. Thiel Fellowship awards $\$ 100,000$ to university students to quit college under the Breakout Labs which underscores his contrarian thinking (O'Dea, 2016). Since beneficiaries of the fellowship have established ventures which have generated value, it is only fair to assert that his ventures cause disruption but in the long-term serve the common good.

Libertarian unethical entrepreneurial practices arise when the entrepreneur begins from greed as the major premise and rationality as a minor premise. This structure of reasoning leads to endorsement of entrepreneurial practices that fall under the categories of fraud, robbery, plunder, and commoditization of other human beings. This defective syllogism leads to a wrong conclusion, resulting in a practice that violates human beings' lives and various intrinsic goods. Even if the framework is averse to the concept of the common good, such violations-even when they are punished as violations of individuals-certainly attack the shared values of particular people.

A libertarian entrepreneur ought to subject his/her appetitive signals to rational evaluation. This process is however bound to fail if the individual does not have the other cardinal virtues and even many other virtues such as magnanimity, fidelity, love, patience and perseverance. Thiel's entrepreneurial journey was enabled by these virtues, given that his start-up venture was supported by his family and friends, and subsequently the ventures that he established were born out of close, amicable relationships that he cultivated at Stanford University and in every venture that he founded or co-founded. While there is no mention of greed in the account of Thiel, Ayn Rand attributes entrepreneurial activities to greed and arguing that greed is a virtue. Various connotations of the word 'greed' cannot account for some vocations that Krieger (1996) presents, yet vocations such as motherhood are inescapable to every human tradition, aside from the equivalence of a child to an enterprise.

The libertarian tradition presumes that although the entrepreneur focuses on self-interest, free-market maximizes the process of choice, production, distribution, and consumption of values and ultimately maximizes the common good (Rand, 1959). There is overwhelming evidence that this presumption is misconceived. Since human beings are prone to lapse into irrationality and are also fallible, the reality of fallibility means that Rand (1962, p. 57) is wrong to argue that "a rational being cannot violate the rational interests of other rational beings". This is because there is no guarantee that a rational being at 6.00 am will continue to be rational at $1.00 \mathrm{pm}$, and thereafter. It is also possible for one to be mistaken in perception and conception of a particular situation, with the consequence that while persuaded that one is acting rationally, $\mathrm{s} / \mathrm{he}$ is not. In any case, while the free market generally serves common good, it can be and has often been manipulated to sub-serve irrational and immoral ends.

The communitarian tradition as expressed in the narratives of Daisaku Ikeda and Vinoba Bhave Usha Thakkar is evident in communitarian entrepreneurial practices which start from the premise that communal good is the primary purpose of the enterprise. Kapur (2005) asserts that: the basic underlying principle of a communitarian ethic is that each individual should be integrally concerned not only with the pursuit of his or her own personal interests but also with the promotion of well-being of as many others as possible. Kapur infers a non-purely-self-interested behaviour, wide and deep concern for social issues, and progressive diminishing of the "elements of appetite and passion" leading to high level of self-control. This does not however mean that the communitarian tradition has no regard for the individual agent. The 
tradition's epistemic position perceives human beings' good to be enabled and enhanced by a flourishing community (Spinosa et al., 1997; Berkowitz, 1997). Other virtues of the tradition include; rationality, cooperation, trust, and honesty which enhance cooperation rather than competition as hallmarks of entrepreneurial practices in communitarian tradition. The violation of the common good is precluded, at least in principle, but in reality, this tradition is not immune to the occurrence of entrepreneurial practices that violate social good arising from human irrationality and fallibility. The communitarian tradition assumes homogeneity which means that social interests that are at variance with the interests of the predominant group will be at risk of being violated.

This leads to the necessity of benevolence to complement other virtues of rationality, commitment, prudence, and devotion. In this tradition, common good is premised to be the starting point and goal of entrepreneurial practices emphasizing on the community in terms of its ontological precedence to the individual and its constitutive import (Marx, 1975; Horvath, 1995; Presbey, 2002; Pope Paul VI, 1967). Despite the precedence and constitutive importance of the community to the individual, entrepreneurial practices par excellence necessarily transcend frameworks. The entrepreneurial practices of Ikeda and Vinoba transcended the original mission and goal and value. Daisaku Ikeda (Pereira, 2008) expanded the range of activities of Soka Gakkai and developed global brands. In order to enable the enterprise to achieve its goals, he diversified its socio-political activities in Japan, USA, and Africa. Ikeda's drive to globalize, diversify, and energize the enterprise alienated some membership of the community, triggered schisms and eventually prompted his ex-communication from the religious community.

Vinoba took part in teaching, studying, spinning, and improving Gandhi's ashram community. He was later on made in charge of a community project at Wardha by Gandhi. And, within a short period, he commissioned a monthly publication of essays on Upanishads in which he enabled people to gain knowledge of themselves and the world. He worked simultaneously, in education sanitation, and hygiene programs and was characterized by
Mahatma Gandhi as a staunch believer in the independence of India and independence of the ordinary people through village industries. Vinoba launched a program to free the poor from dependence on gold, sentential respect, and the Gift of the Land Movement, which prompted many landlords to voluntarily offer land for communal development and benefit in many parts of India. The same appeal yielded massive offers of wealth, labour and life towards communal projects. It is estimated that his venture secured over 4 million acres of land, but nearly 2 million could not be utilized due to legal issues (S.K, 1958). The two communitarian entrepreneurs manifested high commitment to their enterprise and undertook projects to enhance social good.

In contrast to entrepreneurial practices in liberal and libertarian traditions, Ikeda and Vinoba engaged in enterprises that aimed at production of social, spiritual, and intellectual goods. They established, enhanced and developed enterprises which were devoid of capital owners, workers and consumers dichotomy on one hand and stakeholders on the other. These entrepreneurs employed rationality, prudence, fortitude, temperance, and justice. Unlike in the liberal and libertarian traditions where material values are foremost, and in some cases the only values of the enterprise, in communitarian tradition, entrepreneurial practices are aimed at securing and enhancing social and psychological values, such as community, trust, respect, esteem, friendship, equality, security, and care. A more robust entrenched community cherishes desired values, minimizes the necessity for surveillance and formal procedures, while at the same time guaranteeing processes of human transactions. These intrinsic values are fundamentally crucial to human flourishing. It is not incidental that conceptions of utopia project societies in which these social and psychological values are universally enjoyed, in addition to access to material and technical values. There is however the challenge of creating a big community in which trust, friendship, and care apply.

If the communitarian entrepreneur is to excel beyond the confines of a particular community, s/he must cultivate and nourish the notion of a more expansive community, as Daisaku Ikeda (Busacchi, 2016) did. In this respect both Rorty's (1989) and 
Sandel's (1982) concept of solidarity and education of sentiments are useful. There are a number of dangers in this process because, in the process of venturing beyond the community horizon, the sense of community becomes loose and/or coercive means that might be employed as in the communitarian narrative of St. Augustine in building the Catholic Church in Hippo and the narratives of Lord Ling, Lord Kou Chien, and Lord Wen in their practices that transformed China.

Unlike in the case of entrepreneurship in liberal and libertarian traditions where subtle strategies are employed to 'win' customers, investors, and stakeholders, in the communitarian tradition enterprises are mostly considered to be socially desirable and 'dissenters' (those who reject or decline to be part of the enterprise) are haunted. This is because the structure of communitarian entrepreneurial practice is presumed to have communal interests as the starting point and terminus. The other difference is that, while the virtues are more or less the same, they are deployed differently in each of these traditions in MacIntyre's (1988) Whose Justice? Which Rationality?

\section{CONCLUSION}

Social traditions determine the manner in which virtues of entrepreneurial practice are deployed. Although globalization undermines traditions, the power of traditions is such that entrepreneurial practices that extend beyond the 'ideal' environment or that are formed in a social-economic environment that has contrasting practices will tend to manifest some elements of the tradition in the new 'world' or gradually entrench its practices in the new 'world' or fail. Ridley-Duff (2007) contends that community interest companies (CIC) in Britain operate under tensions of individualcommunity interests and regulatory mechanisms to protect 'social' interest. They only provide a recipe for unscrupulous managers and the regulator devises ways of misusing social enterprises.

Generally, certain entrepreneurs' engagements with shareholders, employees, stakeholders and customers are progressively structured by norms and values derived from international covenants on human rights. Motivational aspects of entrepreneurs indeed, reflect distinct moral formation, including the loose moral structure of liberal and libertarian agents. Beneath visible patterns of compliance or non-compliance to international human rights norms and values are entrepreneur virtues, their matrices and various weightings.

In predicating the moral probity of entrepreneurial practice on social good, the presumption is that aspects which are identified as constituting social good have intrinsic and/or instrumental value to a significant proportion of human beings who participate in the enterprise, appropriate and consume the products of the enterprise and live within the social environment of the enterprise. Although all entrepreneurial practices generate values in the forms of commodities, services, and opportunities that enhance people's lives it is only by considering the motivational dimensions of entrepreneurs that the distinction between communitarian practices on one hand and liberal and libertarian practices on the other are justified (Hennessey, 2015)

In order to determine how entrepreneurial practice impacts on social good, it is necessary to distinguish that:

a) Entrepreneurial practices establish new venture;

b) Entrepreneurial practices inaugurate and manage new outfits within the established framework, which are referred to as intrapreneurship (Holt, 1991; Gundogdu, 2012);

c) Entrepreneurial practices innovatively transform workforce, working conditions, structures and processes of management, leading to renewal and growth in product and service range;

d) Practices that arise from a synthesis of a), b), and c) that Gundogdu (2012) refers to as intrapreneurship which involves the establishment of enterprise and innovation in the deepest sense.

In all traditions, entrepreneurial violations of social good arise from human fallibility and instances of irrationality. Howard-Hassman and Donnelley (1999) observe that, without proper institutional 
checks, liberal entrepreneurial practices spawn massive violations of social good under the aegis of the free market. There are instances when enterprises create the demand for goods that ultimately destroy human beings' lives, specifically their health, family and social values and the environment-more so in liberal and libertarian traditions.

Documented instances of entrepreneurial practices that enabled countries to realize economic development provide justification for states' investment in the development of human resources of entrepreneurial bend. Such human resources are more capable of creating values and opportunities. This is the case, notwithstanding the fact that there are many instances of economic growth without development. In any event, given the undeniable disruptions that arise from entrepreneurial practices, it follows that the practices cause some violations (Schumpeter, 1934). The gravity of such violations ought to be evaluated in the context of social and economic gains that are generated, the spread of those gains, their longevity and the fact that human beings could "get more ideas" from enterprises being established. While Global Entrepreneurial Monitoring (GEM) observes that only a small percentage of people engage in entrepreneurial practices, Kurotimi et al. (2007) and Kirzner (1997) note that it is only a small percent that ignores entrepreneurship in public corporations, while large populations of people are variously engaged in derivative outfits. The degrees of agency vary but are never absolutely absent in mundane undertakings such as those of convenient shops.

\section{REFERENCES}

Almond, B. (1990). Alasdair MacIntyre: the virtue of tradition. Journal of Applied Philosophy, 7(1), 99-103.

Aristotle. (1999). Nicomachean Ethics. Terence H. Irwin (ed./trans.), Indianapolis: Hackett Publishing Co. With Introduction, Notes, and Glossary. Second edition.

Beerbohm, E., \& Davis, R. W. (2017). The Common Good: A Buck-Passing Account. Journal of Political Philosophy, 25(4), e60-e79.
Berkowitz, P. (1997). Between Principles: Liberal democracy and the Communitarian Challenge. In Shain, Y. \& Kileman. A. (eds), Democracy: The Challenges Ahead (pp. 19-29). Hampshire: MacMillan.

Bourdieu, P. (1990). The Logic of Practice. Trans. T. Nice. Stanford: Stanford University Press.

Bourdieu, P. (1972). Outline of a Theory of Practice. Cambridge: Cambridge University Press.

Busacchi, V. (2016). The Philosophy of Action of Daisaku Ikeda: A Path of Intra-worldly Spiritual Emancipation. International Journal of Humanities and Social Sciences, 6 (12).

Cordon, M. S. (2014). Passion and Entrepreneurs. In Baker, T., \& Welter, F. (Eds.), The Routledge Companion to Entrepreneurship (pp. 101-112.). New York: Routledge.

Deci, E. \& Ryan, R. M. (1985). Intrinsic Motivation and Self-determination in Human Behaviour. New York: Springer US.

Drucker, P. (1985). Innovation and Entrepreneurship: Practice and Principles. Oxford: Butterworth Heinemann.

Etherington, K. (2013). Narrative approaches to case studies. University of Bristol, UK.

Etzioni, A. (1988). The Moral Dimension: Towards a New Economics. New York: The Free Press.

Fenton, C., \& Langley, A. (2011). Strategy as practice and the narrative turn. Organization Studies, 32(9), 1171-1196.

Friedman, M. (1962). Capitalism and Freedom. Chicago: University of Chicago Press.

Fromm, H. (1991). One-dimensional Man: Studies in Ideology of Advanced Industrial Society. New York: Routledge.

Gartner, W. B., Stam, E., Thompson, N., \& Verduyn, K. (2016). Entrepreneurship as practice: Grounding contemporary practice theory into entrepreneurship studies. 
Entrepreneurship \& Regional Development, 28 (9-10), 813-816.

Gedvilienè, G., \& Bortkevičienè, V. (2013). The importance of key competences in the context of lifelong learning. Proceedings of ICERI201, 4646-4653.

Giddens, A. (1984). The Constitution of Society: Outline of the Theory of Structuration. Cambridge: Polity Press.

Gilder, G. (1982). A Conversation in Economics. Dialogue, New York.

Girard, R. (1987). Things Hidden Since the Foundation of the World, trans. Stephen Bann and Michael Metteer. Stanford: Stanford University Press.

Gündoğdu, M. Ç. (2012). Re-thinking entrepreneurship, intrapreneurship, and innovation: A multi-concept perspective. Procedia-Social and Behavioral Sciences, 41, 296-303.

Hayek, F. A. (1944). The Road to Serfdom. London: Routledge.

Hennessey, R. (2015). All Entrepreneurship is 'Social Entrepreneurship'. The Entrepreneur. entrepreneur.com/article/247137

Hisrich, R. D. \& Peters, M. P. (2002). Entrepreneurship. (5 $5^{\text {th }}$ Ed.). Boston, MA: Irwin/McGraw Hill.

Holt, D. (1991). Entrepreneurship: New Ventures Creation, Prentice Hall,

Horvath, C. M. (1995). Excellence v. effectiveness: MacIntyre's critique of business. Business Ethics Quarterly, 499-532.

Howard-Hassman, R. \& Donnelley, J. (1999). Liberalism and Human Rights: A Necessary Connection. In Ishay, M. R. (2007) Human Rights Reader: Major Political Essays, Speeches, and Documents from Ancient Times to the Present (pp. 404-409.). New York: Routledge.
Huebert, J. (2010). Libertarianism Today. Praeger: Santa Barbara.

Irving, K. (2011). The Neo-conservative Persuasion: Selected Essays, 1942-2009. New York: Basic Books.

Johansson, A. W. (2004). Narrating the entrepreneur. International Small Business Journal, 22(3), 273-293.

Kant, I. (1996). Practical Philosophy. Gregor, M. (ed.). Cambridge: Cambridge University Press.

Kapur, B. K. (1999). Harmonization between communitarian ethics and market economics. Journal of Markets \& Morality, 2(1), 35-52.

Keynes, J. M. (1973). Donald Moggeridge (ed.) The Collected Writings of J. M. Keynes. London: Macmillan for the Royal Economic Society.

Kirzner, I. M. (1997). Entrepreneurial discovery and the competitive market process: An Austrian approach. Journal of economic Literature, 35(1), 60-85.

Klein, P. G. \& Bullock, J. B. (2006). Can Entrepreneurship Be Taught? Journal of Agricultural and Applied Economics, 38(2), 429-439.

Korsgaard, C. (1996) Sources of Normativity. Foreword by Onora O'Neill. Cambridge: Cambridge University Press

Krieger, M. H. (1996). Entrepreneurial Vocations. Atlanta: Scholars Press.

Kurotimi, M. F., Franklin, A., Aladei, G., \& Helen, O. (2017). Entrepreneurship Education as a 21st Century Strategy for Economic Growth and Sustainable Development. International Journal of Social, Behavioural, Educational, Economic, Business and Industrial Engineering, 11(9), 2168-2179.

Lasch, C. (1978). The Culture of Narcissism. W. W. New York: Norton and Co.

Locke, J. (1997). Political Essays. Mark Goldie (ed.). Cambridge: Cambridge University

32 This work is licensed under a Creative Commons Attribution 4.0 International License. 
MacIntyre, A. (1984). After Virtue: A Study in Moral Theory. Notre Dame: University of Notre Dame.

MacIntyre, A. (1988). Whose Justice? Which Rationality? Indiana: University of Notre Dame Press.

Marx, K. (1975). Economic and Philosophical Manuscripts of 1844 . Translated by R. Livingstone and G. Benton, in ed. Q. Hoare. Karl Marx: Early Writings. New York: Vintage Books, 278-400.

Nozick, R. (1974). Anarchy, state, and utopia (Vol. 5038). New York: Basic Books.

O’Dea, M. (2016). Political Ideology and Economic Activity: Peter Thiel's Libertarian Entrepreneurship. German Historical Institute.

Ortner, S. B. (2001). Commentary: Practice, power and the past. Journal of Social Archaeology, 1(2), 271-278.

Pereira, R. A. (2008). The Transplantation of Soka Gakkai to Brazil: Building The Closest Organization to the Heart of IkedaSensei. Japanese journal of religious studies, 95-113.

Peters, T. J. \& Waterman Jr., R. H. (1982). In Search of Excellence Lessons from America's Best-Run Companies. New York: Harper \& Row.

Politis, D. (2005). The process of entrepreneurial learning: A conceptual framework. Entrepreneurship theory and practice, 29(4), 399-424.

Pope Paul VI. (1967). Poplorum Progression: On the Development of Peoples. Encyclical. Vatican.

Presbey, G. M. (2003). Unfair distribution of resources in Africa: What should be done about the ethnicity factor? Human Studies, 26(1), 2140.

Rand, A. (1957). Atlas Shrugged. New York: Mentor.
Rand, A. (1964). The Virtue of Selfishness. New York: New American Library.

Rawls, J. (1971). A Theory of Justice. Cambridge: The Belknap Press of Harvard University Press.

Reiman, J. (1996). Critical Moral Liberalism: Theory and Practice. New York: Lanham Rowman and Littlefield Publishers.

Reynolds, T. E. (2006). The Broken Whole: Philosophical Steps towards Global Solidarity. New York: State University of New York.

Ridley-Duff, R. (2007). Communitarian perspectives on social Enterprise. Corporate governance: an international review, 15(2), 382-392.

Rorty, R. (1989). Contingency, Irony, and Solidarity. Cambridge: Cambridge University Press.

S.K. (1958). The Land Gift Movement in India: Vinoba Bhave and His Achievement. The World Today, 487-495.

Sandel, M. (1982). Liberalism and the Limits of Justice. Cambridge: Cambridge University Press.

Sapienza, H. J., \& Korsgaard, M. A. (1996). Procedural justice in entrepreneur-investor relations. Academy of management Journal, 39(3), 544-574.

Schumpeter, J. A. (1934). The Theory of Economic Development. Cambridge: Harvard University Press.

Selznick, P. (1992). The Moral Commonwealth: Social Theory and the Promise of Community. Berkeley: University of California Press.

Shaw, B. (1997). Sources of virtue: The market and the community. Business Ethics Quarterly, 3350 .

Smith, A. (1976). An Inquiry into the Nature and Causes of the Wealth of Nations (Vol 2). Campbell, R. H. \& Skinner, A. S. (Ed.). Indianapolis: Liberty Press.

33 This work is licensed under a Creative Commons Attribution 4.0 International License. 
Solomon, G., Duffy, S. and Tarabishy, A. (2002). The state of entrepreneurship education in the United States: a nationwide survey and analysis. International Journal of Entrepreneurship Education. 1(1), 65-86.

Spinosa, C., Flores, F. \& Dreyfeus, H. L. (1997). Entrepreneurship, Democratic Action, and the cultivation of Solidarity: Disclosing New Worlds. MIT: Cambridge.

Theobald, P. \& Dinkleman, T. (1995). The Parameters of the Liberal-Communitarian Debate. Education Resource Information Center (ERIC).

Torcello, L. (2011). Sophism and moral agnosticism, or, how to tell a relativist from a pluralist. The Pluralist, 6(1), 87-108.

Vesper, K. H., \& Gartner, W. B. (1997). Measuring progress in entrepreneurship education. Journal of Business venturing, 12(5), 403-421. 